Article

\title{
New Tripeptide Derivatives Asterripeptides A-C from Vietnamese Mangrove-Derived Fungus Aspergillus terreus LM.5.2
}

\author{
Elena V. Girich ${ }^{1}{ }^{(D}$, Anton B. Rasin ${ }^{1}$, Roman S. Popov ${ }^{1}$, Ekaterina A. Yurchenko ${ }^{1} \mathbb{D}$, Ekaterina A. Chingizova ${ }^{1}$, \\ Phan Thi Hoai Trinh ${ }^{2}$ (D), Ngo Thi Duy Ngoc ${ }^{2}$, Mikhail V. Pivkin ${ }^{1}$, Olesya I. Zhuravleva ${ }^{3, *}$ \\ and Anton N. Yurchenko ${ }^{1, * \mathbb{D}}$
}

check for

updates

Citation: Girich, E.V.; Rasin, A.B.;

Popov, R.S.; Yurchenko, E.A.;

Chingizova, E.A.; Trinh, P.T.H.; Ngoc,

N.T.D.; Pivkin, M.V.; Zhuravleva,

O.I.; Yurchenko, A.N. New Tripeptide

Derivatives Asterripeptides A-C

from Vietnamese Mangrove-Derived

Fungus Aspergillus terreus LM.5.2.

Mar. Drugs 2022, 20, 77. https://

doi.org/10.3390/md20010077

Academic Editor: Vassilios Roussis

Received: 30 December 2021

Accepted: 13 January 2022

Published: 17 January 2022

Publisher's Note: MDPI stays neutral with regard to jurisdictional claims in published maps and institutional affiliations.

Copyright: (c) 2022 by the authors. Licensee MDPI, Basel, Switzerland. This article is an open access article distributed under the terms and conditions of the Creative Commons Attribution (CC BY) license (https:// creativecommons.org/licenses/by/ $4.0 /)$.
1 G.B. Elyakov Pacific Institute of Bioorganic Chemistry, Far Eastern Branch of the Russian Academy of Sciences, Prospect 100-Letiya Vladivostoka, 159, 690022 Vladivostok, Russia; ev.girich@piboc.dvo.ru (E.V.G.); rasin_ab@piboc.dvo.ru (A.B.R.); popov_rs@piboc.dvo.ru (R.S.P.); eyurch@piboc.dvo.ru (E.A.Y.); chingizova_ea@piboc.dvo.ru (E.A.C.); pivkin@piboc.dvo.ru (M.V.P.)

2 Department of Marine Biotechnology, Nhatrang Institute of Technology Research and Application, Vietnam Academy of Science and Technology, Nha Trang 650000, Vietnam; phanhoaitrinh@nitra.vast.vn (P.T.H.T.); ngoduyngoc@nitra.vast.vn (N.T.D.N.)

3 School of Natural Sciences, Far Eastern Federal University, 690922 Vladivostok, Russia

* Correspondence: zhuravleva.oi@dvfu.ru (O.I.Z.); yurchenkoan@piboc.dvo.ru (A.N.Y.); Tel.: +7-423-231-1168 (A.N.Y.)

\begin{abstract}
Three new tripeptide derivatives asterripeptides A-C (1-3) were isolated from Vietnamese mangrove-derived fungus Aspergillus terreus LM.5.2. Structures of isolated compounds were determined by a combination of NMR and ESIMS techniques. The absolute configurations of all stereocenters were determined using the Murfey's method. The isolated compounds 1-3 contain a rare fungi cinnamic acid residue. The cytotoxicity of isolated compounds against several cancer cell lines and inhibition ability of sortase A from Staphylococcus aureus of asterripeptides A-C were investigated.
\end{abstract}

Keywords: marine-derived fungi; mangrove-derived fungi; secondary metabolites; diketopiperazines; tripeptide derivatives; cinnamic acid; sortase A; cytotoxicity

\section{Introduction}

The genus Aspergillus is a group of filamentous fungi, which today consists of more than 250 species. Moreover, this genus has been subdivided into several subgenera and sections based on morphology and genetics, such as subgenera Nidulantes, Circumdati, Fumigati, Terrei, Candidi, and so on. The section Terrei includes Aspergillus terreus along with its varieties, as well as $A$. niveus, A. carneus, A. niveus var. indicus, A. allahabadii, A. ambiguous, and $A$. microcysticus [1]. Fungi of the section Terrei are mainly characterized by the several metabolite classes such as butenolides [2] and other polyketides [3,4], sesquiterpenoids [5-7], meroterpenoids [8], and bisindolebenzoquinone alkaloids [9].

Aspergillus terreus is a cosmopolite species with high biotechnological potential [10]. For instance, A. terreus NIH2624 contains 28 polyketide synthase (PKS) genes, 22 nonribosomal peptide synthetase (NRPS) genes, 1 hybrid PKS/NRPS gene, 2 PKS-like genes, and 15 NRPS-like genes [11]. Owing to the diversity of such synthase gene clusters, $A$. terreus produces a huge amount of secondary metabolites with very large structural variety. Marine environments have an additional effect on the structural features of $A$. terreus bioactive metabolites. Marine-derived $A$. terreus strains were described as producers of butyrolactones with anti-allergic, anti-inflammatory, and antiviral activities [2,12], an unusual antimicrobial $N$-phenyl-carbamic acid trimer [13] and a cytotoxic tetrapeptide [14]. 
Peptide derivatives are a very rare type of $A$. terreus metabolite [14,15]. Overall, low-weight marine fungal peptides are not as widespread as alkaloids, polyketides, and terpenoids, but they undoubtedly have pharmaceutical potential, thanks to their structural peculiarities and wide bioactivity spectrum [16]. Peptides of marine microorganisms, including fungi, can be biosynthetically produced by ribosomal and non-ribosomal peptidesynthase action, which can explain the presence of unique structural features, such as $\mathrm{D}$-amino acids, $\mathrm{N}$-terminally attached fatty acid chains, $\mathrm{N}$ - and $\mathrm{C}$-methylated residues, $\mathrm{N}$-formylated residues, heterocyclic elements, and glycosylated amino acids, as well as phosphorylated residues, among others [17]. For example, peptaibols—antibiotic active peptide-derivative compounds produced mainly by fungal species of the genus Trichoderma [18]. Moreover, there are cytotoxic, antiviral, antidiabetic, and anti-inflammatory peptides originating from marine fungi [19].

Previously, we reported a number of alkaloids, polyketides, and terpenoids from a Vietnamese mangrove-derived strain of Aspergillus terreus LM.5.2 [20].

Herein, we described the isolation and structural elucidation of three peptide-derivative secondary metabolites (Figure 1) of the same Aspergillus terreus LM.5.2 strain. Moreover, their cytotoxic activity against a number of malignant human cancer cells and nonmalignant rat cardiomyocytes $\mathrm{H} 9 \mathrm{c} 2$ cells, as well as inhibition of sortase A enzyme from Staphylococcus aureus, were investigated.

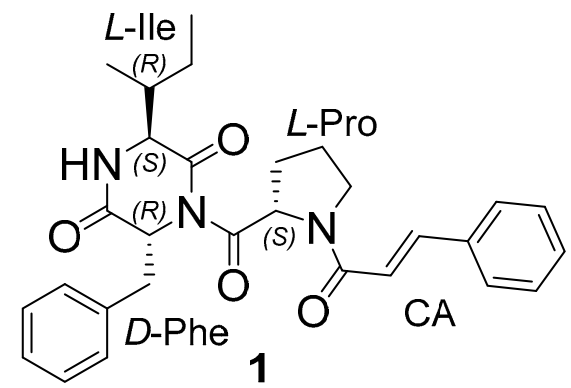

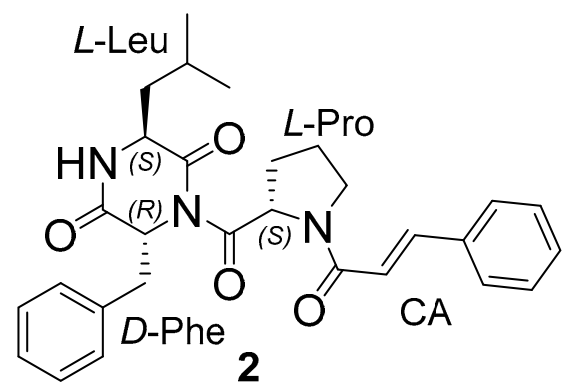<smiles>CC(C)C(C)C1NC(=O)[C@@H](Cc2ccccc2)N(C(=O)[C@@H]2CCCN2C(=O)/C=C/c2ccccc2)C1=O</smiles>

Figure 1. The structure of isolated 1-3 compounds.

\section{Results}

The molecular formula of $\mathbf{1}$ was determined as $\mathrm{C}_{29} \mathrm{H}_{33} \mathrm{~N}_{3} \mathrm{O}_{4}$ by the HRESIMS peak $[\mathrm{M}-\mathrm{H}]^{-}$at $m / z 486.2399$ (Figure S8, Supplementary Material), which was confirmed by the ${ }^{13} \mathrm{C}$ NMR data. A thorough inspection of the ${ }^{1} \mathrm{H}$ and ${ }^{13} \mathrm{C}$ NMR data (Table 1, Figures S1-S3, Supplementary Material) of 1 identified the presence of two methyl groups $\left(\delta_{\mathrm{H}} 0.85,0.89 ; \delta_{\mathrm{C}} 12.1,15.7\right)$, five methylene groups $\left(\delta_{\mathrm{H}} 1.24,1.40,2.09,2.14,2.17,2.50,3.28\right.$, $\left.3.33,3.79,3.90 ; \delta_{\mathrm{C}} 24.1,24.4,29.7,38.5,47.6\right)$, four aliphatic $\left(\delta_{\mathrm{H}} 1.97,2.54,5.10,5.22 ; \delta_{\mathrm{C}}\right.$ $38.2,58.2,59.4,61.7)$ and twelve aromatic $\left(\delta_{\mathrm{H}} 6.73,7.10(2 \mathrm{H}), 7.29(2 \mathrm{H}), 7.30,7.35,7.36(2 \mathrm{H})\right.$, $\left.7.51(2 \mathrm{H}), 7.66 ; \delta_{\mathrm{C}} 117.9,127.8,127.9(2 \mathrm{C}), 128.7(2 \mathrm{C}), 128.8(2 \mathrm{C}), 129.7,130.5(2 \mathrm{C}), 142.8\right)$ methine groups, two $s p^{2}$-quarternary carbons $\left(\delta_{\mathrm{C}} 135.0,135.1\right)$, four amide carbonyl groups $\left(\delta_{\mathrm{C}} 164.6,168.2,170.1,174.7\right)$, and one NH-singlet $\left(\delta_{\mathrm{H}} 5.57\right)$.

Detailed analysis of the HMBC and ${ }^{1} \mathrm{H}^{-1} \mathrm{H}$ COSY and ROESY spectra (Figure 2, Figures S4-S7, Supplementary Material) led to the identification of three amino acid residues, including isoleucine (Ile), proline (Pro), and phenylalanine (Phe). The HMBC correlations (Figure $2 \mathrm{a})$ from $\mathrm{H}-1\left(\delta_{\mathrm{H}} 5.57\right)$ to $\mathrm{C}-24\left(\delta_{\mathrm{C}} 58.2\right)$ and $\mathrm{C}-32\left(\delta_{\mathrm{C}} 168.2\right)$, from H-2 $\left(\delta_{\mathrm{H}} 2.54\right)$ to $\mathrm{C}-32$, and from $\mathrm{H}-24\left(\delta_{\mathrm{H}} 5.57\right)$ to $\mathrm{C}-7$ indicated the presence of a diketopiperazine ring formed from residues of isoleucine and phenylalanine. The HMBC correlations (Figure 2a) from H-16 $\left(\delta_{\mathrm{H}} 6.73\right)$ to $\mathrm{C}-15\left(\delta_{\mathrm{C}} 164.6\right), \mathrm{C}-17\left(\delta_{\mathrm{C}} 142.8\right)$, and C-18 $\left(\delta_{\mathrm{C}} 135.1\right)$; from $\mathrm{H}-17\left(\delta_{\mathrm{H}} 6.73\right)$ to $\mathrm{C}-16\left(\delta_{\mathrm{C}} 117.9\right), \mathrm{C}-18$, and $\mathrm{C}-19\left(\delta_{\mathrm{C}} 127.9\right)$; from $\mathrm{H}-19\left(\delta_{\mathrm{H}} 7.51\right)$ to C-17, C-21 $\left(\delta_{\mathrm{C}} 129.7\right)$, and C-23 $\left(\delta_{\mathrm{C}} 127.9\right)$; from H-20 $\left(\delta_{\mathrm{H}} 7.36\right)$ to $\mathrm{C}-22\left(\delta_{\mathrm{C}} 128.8\right)$ and C-18; from $\mathrm{H}-21\left(\delta_{\mathrm{H}} 7.35\right)$ to $\mathrm{C}-19$ and C-23; and from $\mathrm{H}-23\left(\delta_{\mathrm{H}} 7.51\right)$ to $\mathrm{C}-21, \mathrm{C}-19$, and C-17, along with the vicinal coupling constant $\left({ }^{3} \mathrm{~J}_{\mathrm{H} 16-\mathrm{H} 17}=15.5 \mathrm{~Hz}\right)$ and MS/MS data (the peak at $m / z 200.1061\left(\left[\mathrm{C}_{13} \mathrm{H}_{14} \mathrm{NO}\right]^{-}\right)$corresponding to cinnamic acid (CA) with Pro fragment, 
and the peak at $m / z 131.0487\left(\left[\mathrm{C}_{9} \mathrm{H}_{7} \mathrm{O}\right]^{-}\right)$corresponding to $\left.\mathrm{CA}\right)$, indicated the presence of a trans-cinnamic acid residue (Figure S8, Supplementary Material). This moiety was bound to the proline residue through the carboxyl group of the former and the amino group of the latter, as the ROESY spectrum contained correlations between $\mathrm{H}-13 \mathrm{a}\left(\delta_{\mathrm{H}} 3.93\right)$ and $\mathrm{H}-16$ $\left(\delta_{\mathrm{H}} 6.73\right), \mathrm{H}-13 \mathrm{~b}\left(\delta_{\mathrm{H}} 3.79\right)$, and $\mathrm{H}-16$, as well as between $\mathrm{H}-13 \mathrm{a} / \mathrm{b}$ and $\mathrm{H}-17\left(\delta_{\mathrm{H}} 7.66\right)$. Thus, the planar structure of compound 1 was determined.

Table 1. ${ }^{1} \mathrm{H}$ and ${ }^{13} \mathrm{C}$ NMR spectroscopic data $\left(\delta\right.$ in ppm, $\left.\mathrm{CDCl}_{3}\right)$ for $\mathbf{1}$.

\begin{tabular}{|c|c|c|c|c|c|c|}
\hline & Pos. & $\delta_{C}$, Mult & $\delta_{H}(J$ in $\mathrm{Hz})$ & НМВС & COSY & ROESY \\
\hline \multirow{7}{*}{ Ile } & 1 & $(\mathrm{NH})$ & 5.57, brs & $2,7,24,32$ & 2 & 2,24 \\
\hline & 2 & $59.4, \mathrm{CH}$ & $2.54, \mathrm{~d}(2.7)$ & $3,4,5,7$ & 3 & 5,6 \\
\hline & 3 & $38.2, \mathrm{CH}$ & $1.97, \mathrm{~m}$ & $4,5,7$ & $2,4,5$ & $1,4,6$ \\
\hline & 4 & $15.7, \mathrm{CH}_{3}$ & $0.89, \mathrm{~d}(7.2)$ & $2,3,5$ & 3 & 1,3 \\
\hline & 5 & 24.1, $\mathrm{CH}_{2}$ & $\begin{array}{l}1.24, \mathrm{~m} \\
1.40, \mathrm{~m}\end{array}$ & $\begin{array}{c}2,3,4,6,10 \\
2,3,4,6\end{array}$ & & 2 \\
\hline & 6 & $12.1, \mathrm{CH}_{3}$ & $0.85, \mathrm{t}(7.4)$ & 3,5 & $5 a, 5 b$ & 2,3 \\
\hline & 7 & $170.1, \mathrm{C}$ & & & & \\
\hline \multirow{8}{*}{ Pro } & 9 & 174.7, C & & & & \\
\hline & 10 & 61.7, $\mathrm{CH}$ & 5.10, dd $(8.9,4.1)$ & $9,11,12,13$ * & 11 & 2,11 \\
\hline & \multirow{2}{*}{11} & \multirow{2}{*}{ 29.7, $\mathrm{CH}_{2}$} & $2.14, \mathrm{~m}$ & $9,10,12,13$ & 10,12 & \multirow{2}{*}{13} \\
\hline & & & $2.50, \mathrm{~m}$ & $9,10,12,13$ & 10,12 & \\
\hline & \multirow{2}{*}{12} & \multirow{2}{*}{$24.4, \mathrm{CH}_{2}$} & $2.09, \mathrm{~m}$ & $10,11,13$ & 11,13 & \multirow{2}{*}{13} \\
\hline & & & $2.17, \mathrm{~m}$ & $10,11,13$ & 11,13 & \\
\hline & \multirow{2}{*}{13} & \multirow{2}{*}{ 47.6, $\mathrm{CH}_{2}$} & 3.79 , dt $(9.2,7.1)$ & 11,12 & 12 & \multirow{2}{*}{$\begin{array}{c}11, \begin{array}{c}12,16 \\
17\end{array}\end{array}$} \\
\hline & & & $3.90, \mathrm{~m}$ & 11,12 & 12 & \\
\hline \multirow{9}{*}{$\mathrm{CA}$} & 15 & $164.6, \mathrm{C}$ & & & & \multirow{9}{*}{$\begin{array}{c}13,22,23 \\
13\end{array}$} \\
\hline & 16 & $117.9, \mathrm{CH}$ & $6.73, \mathrm{~d}(15.5)$ & $15,17,18$ & 17 & \\
\hline & 17 & $142.8, \mathrm{CH}$ & $7.66, \mathrm{~d}(15.6)$ & $16,18,19,23$ & 16 & \\
\hline & 18 & $135.1, \mathrm{C}$ & & & & \\
\hline & 19 & $127.9, \mathrm{CH}$ & 7.51 & $17,21,23$ & 20 & \\
\hline & 20 & $128.8, \mathrm{CH}$ & $7.36, \mathrm{~m}$ & 18,22 & 19,21 & \\
\hline & 21 & 129.7, CH & $7.35, \mathrm{~m}$ & 19,23 & 20,22 & \\
\hline & 22 & $128.8, \mathrm{CH}$ & $7.36, \mathrm{~m}$ & 18,20 & 21,23 & \\
\hline & 23 & $127.9, \mathrm{CH}$ & 7.51 & $17,19,21$ & 22 & \\
\hline \multirow{10}{*}{ Phe } & 24 & $58.2, \mathrm{CH}$ & $5.22, \mathrm{t}(4.5)$ & $7,9 *, 25,26,32$ & 25 & \multirow{4}{*}{$\begin{aligned} & 25 \\
11, & 24,26 \\
& 27\end{aligned}$} \\
\hline & \multirow{2}{*}{25} & \multirow{2}{*}{$38.5, \mathrm{CH}_{2}$} & 3.28 , dd $(14.0,4.2)$ & $24,26,27,31,32$ & 24 & \\
\hline & & & 3.33 , dd $(14.0,4.9)$ & $24,26,27,31,32$ & 24 & \\
\hline & 26 & $135.0, \mathrm{C}$ & & & & \\
\hline & 27 & $130.5, \mathrm{CH}$ & $7.10, \mathrm{~m}$ & $25,29,31$ & 28 & 25 \\
\hline & 28 & $128.7, \mathrm{CH}$ & $7.29, \mathrm{~m}$ & 26,30 & 27,29 & 25 \\
\hline & 29 & $127.8, \mathrm{CH}$ & $7.30, \mathrm{~m}$ & 27,31 & 28,30 & \\
\hline & 30 & 128.7, $\mathrm{CH}$ & $7.29, \mathrm{~m}$ & 26,28 & 29,31 & \\
\hline & 31 & $130.5, \mathrm{CH}$ & $7.10, \mathrm{~m}$ & $25,27,29$ & 30 & \\
\hline & 32 & $168.2, \mathrm{C}$ & & & & \\
\hline
\end{tabular}

*-weak interaction.

The absolute configurations of all stereocenters in 1 were established by Marfey's method [21]. Analysis of L-FDAA derivatives of amino acid residues obtained by acid hydrolysis of compound 1 showed them to be derivatives of L-Ile, L-Pro, and D-Phe standard samples (Figures S25-S28, Supplementary Material). Thus, the configurations of chiral centers at C-2, C-10, and C-24 were determined as $2 S, 10 S$, and $24 R$, respectively. Compound 1 was named asterripeptide A.

The molecular formula of 2 was suggested as $\mathrm{C}_{29} \mathrm{H}_{33} \mathrm{~N}_{3} \mathrm{O}_{4}$ by the HRESIMS data (the $[\mathrm{M}+\mathrm{Na}]^{+}$peak at $m / z 439.2367$ (Figure S16, Supplementary Material)) and was confirmed by ${ }^{13} \mathrm{C}$ NMR spectra (Figure S10, Supplementary Material).

A detailed ${ }^{1} \mathrm{H}$ and ${ }^{13} \mathrm{C}$ NMR data comparison of 1 and 2 revealed a very close similarity with the exception of the signals in diketopiperazine moiety, namely $C-3\left(\delta_{C} 40.7\right), C-4$ 
$\left(\delta_{\mathrm{C}} 24.4\right), \mathrm{C}-5\left(\delta_{\mathrm{C}} 23.1\right)$, and C-6 $\left(\delta_{\mathrm{C}} 20.7\right)$, and a splitting pattern of the protons on these carbons (Table 2, Figures S9-S11, Supplementary Material). These data, along with HMBC correlations (Figure 3a, Figure S13, Supplementary Material) from $\mathrm{H}-4\left(\delta_{\mathrm{H}} 2.07\right)$ to C-2 $\left(\delta_{\mathrm{C}} 52.6\right)$ and C-3, from $\mathrm{H}-5\left(\delta_{\mathrm{H}} 0.88\right)$ to C-2 and C-3, as well as from H-6 $\left(\delta_{\mathrm{H}} 0.70\right)$ to C-3, suggest the presence of leucine residue (Leu) in the diketopiperazine ring of 2 , instead of Ile in $\mathbf{1}$. Thus, compound $\mathbf{2}$ was determined to be an isomer of $\mathbf{1}$.
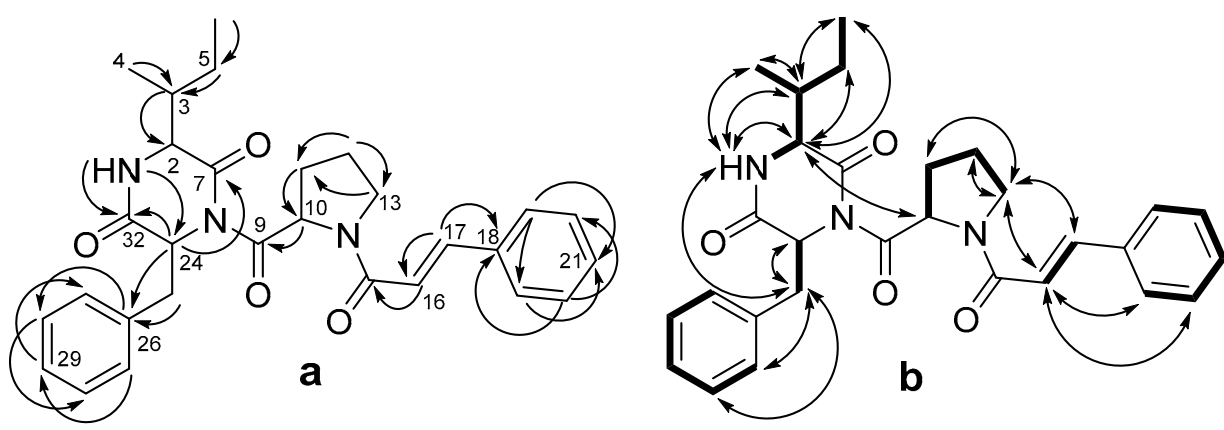

Figure 2. The key HMBC (a) and ${ }^{1} \mathrm{H}^{-1} \mathrm{H}$ COSY and ROESY (b) correlation of $\mathbf{1}$.

Table 2. ${ }^{1} \mathrm{H}$ and ${ }^{13} \mathrm{C}$ NMR spectroscopic data ( $\delta$ in ppm, $\mathrm{CDCl}_{3}$ ) for 2.

\begin{tabular}{|c|c|c|c|c|c|c|}
\hline & Pos. & $\delta_{C}$, Mult & $\delta_{H}(J$ in $\mathrm{Hz})$ & НМВС & COSY & ROESY \\
\hline \multirow{7}{*}{ Leu } & 1 & $(\mathrm{NH})$ & 5.62 , brs & $2,7,24,32$ & 2 & 2,24 \\
\hline & 2 & $52.6, \mathrm{CH}$ & $2.48, \mathrm{dd}(8.8,3.8)$ & $3,4,5,7$ & 3 & 5,6 \\
\hline & 3 & $40.7, \mathrm{CH}_{2}$ & $\begin{array}{l}1.67, \mathrm{~m} \\
1.52, \mathrm{~m}\end{array}$ & $2,3,4,5,6,7,32$ & $2,4,5$ & $1,4,6$ \\
\hline & 4 & $24.4, \mathrm{CH}$ & 2.07, m & $2,3,5,6$ & & 2 \\
\hline & 5 & $23.1, \mathrm{CH}_{3}$ & $0.88, \mathrm{~d}(6.2)$ & $2,3,6$ & 3 & 1,3 \\
\hline & 6 & $20.7, \mathrm{CH}_{3}$ & $0.70, d(6.3)$ & 3,5 & $5 a, 5 b$ & 2,3 \\
\hline & 7 & $170.8, \mathrm{C}$ & & & & \\
\hline \multirow{8}{*}{ Pro } & 9 & $175.0, \mathrm{C}$ & & & & \\
\hline & 10 & $61.8, \mathrm{CH}$ & $5.17, \mathrm{dd}(8.6,3.6)$ & 9,13 * & 11 & 2,11 \\
\hline & 11 & $29.7 \mathrm{CH}_{2}$ & $2.12, \mathrm{~m}$ & $9,10,12,13$ & 10,12 & \\
\hline & 11 & $29.7, \mathrm{CH}_{2}$ & $2.48, \mathrm{dd}(8.8,3.8)$ & $9,10,12,13$ & 10,12 & 13 \\
\hline & & & $2.11, \mathrm{~m}$ & $10,11,13$ & 11,13 & \\
\hline & 12 & $29.6, \mathrm{CH}_{2}$ & $1.26, \mathrm{~m}$ & $10,11,13$ & 11,13 & 13 \\
\hline & & & $3.93, \mathrm{~m}$ & 11,12 & 12 & $11,12,16$, \\
\hline & 13 & $47.6, \mathrm{CH}_{2}$ & 3.79 , dd $(16.3,7.3)$ & 11,12 & 12 & 17 \\
\hline \multirow{9}{*}{$\mathrm{CA}$} & 15 & 164.6, C & & & & \\
\hline & 16 & $117.8, \mathrm{CH}$ & $6.73, \mathrm{~d}(15.4)$ & $15,17,18$ & 17 & $13,22,23$ \\
\hline & 17 & $142.9, \mathrm{CH}$ & $7.66, \mathrm{~d}(15.5)$ & $16,18,19,23$ & 16 & 13 \\
\hline & 18 & $135.1, \mathrm{C}$ & & & & \\
\hline & 19 & $127.9, \mathrm{CH}$ & $7.52, \mathrm{~d}(2.3)$ & $17,21,23$ & 20 & \\
\hline & 20 & $128.7, \mathrm{CH}$ & $7.29, \mathrm{~m}$ & 18,22 & 19,21 & \\
\hline & 21 & $129.8, \mathrm{CH}$ & $7.36, \mathrm{~m}$ & 19,23 & 20,22 & \\
\hline & 22 & $128.7, \mathrm{CH}$ & $7.29, \mathrm{~m}$ & 18,20 & 21,23 & \\
\hline & 23 & $127.9, \mathrm{CH}$ & $7.52, \mathrm{~d}(2.3)$ & $17,19,21$ & 22 & \\
\hline \multirow{10}{*}{ Phe } & 24 & $58.6, \mathrm{CH}$ & $5.23, \mathrm{t}(4.5)$ & $7,9,25,26,32$ & 25 & 25 \\
\hline & 25 & $38.4 \mathrm{CH}_{2}$ & 3.28 , dd $(14.0,4.9)$ & $24,26,27,31,32$ & 24 & $11,24,26$, \\
\hline & 25 & $38.4, \mathrm{CH}_{2}$ & $3.35, \mathrm{dd}(14.0,5.0)$ & $24,26,27,31,32$ & 24 & 27 \\
\hline & 26 & $135.2, \mathrm{C}$ & & & & \\
\hline & 27 & $130.4, \mathrm{CH}$ & $7.13, \mathrm{~d}(1.8)$ & $25,29,31$ & 28 & 25 \\
\hline & 28 & $128.8, \mathrm{CH}$ & $7.29, \mathrm{~m}$ & 26,30 & 27,29 & 25 \\
\hline & 29 & 127.7, $\mathrm{CH}$ & $7.36, \mathrm{~m}$ & 27,31 & 28,30 & \\
\hline & 30 & $128.8, \mathrm{CH}$ & $7.29, \mathrm{~m}$ & 26,28 & 29,31 & \\
\hline & 31 & $130.4, \mathrm{CH}$ & $7.13, \mathrm{~d}(1.8)$ & $25,27,29$ & 30 & \\
\hline & 32 & $168.1, \mathrm{C}$ & & & & \\
\hline
\end{tabular}



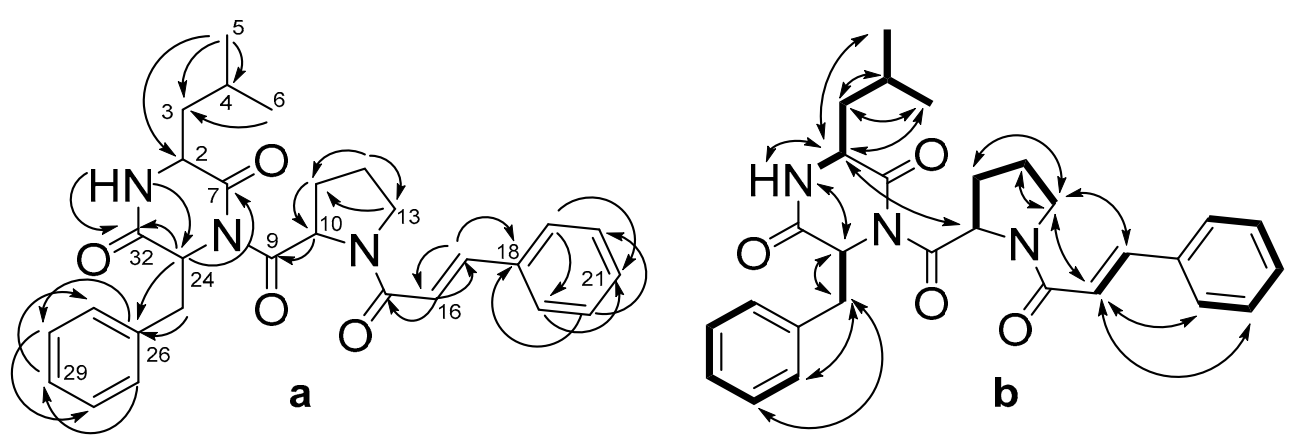

Figure 3. The key HMBC (a) and ${ }^{1} \mathrm{H}^{-1} \mathrm{H}$ COSY and ROESY (b) correlations of 2.

The absolute configurations of all stereocenters in 2 were established by Marfey's method [21]. Analysis of $L$-FDAA derivatives of amino acid residues obtained by acid hydrolysis of compound 2 showed them to be derivatives of $L$-Leu, L-Pro, and D-Phe standard samples (Figures S29-S32, Supplementary Material). Thus, the configurations of chiral centers at C-2, C-10, and C-24 were determined to be $2 S, 10 S$, and $24 R$ respectively. Compound 2 was named asterripeptide B.

The HRESIMS peak at $m / z 472.2238[\mathrm{M}-\mathrm{H}]^{-}$(Figure S24, Supplementary Material) obtained for compound 3 corresponded with the molecular formula $\mathrm{C}_{28} \mathrm{H}_{31} \mathrm{O}_{4} \mathrm{~N}_{3}$, which was confirmed by NMR data (Figures S17-S19, Supplementary Material).

Detailed analysis of HMBC and ${ }^{1} \mathrm{H}-{ }^{1} \mathrm{H}$ COSY and ROESY spectra (Table 3, Figure 4, Figures S21-S23, Supplementary Material) showed the molecule of compound 3 to be mostly structurally close to asterripeptide A (1), except for the signals in diketopiperazine moiety. The HMBC correlations from H-3 $\left(\delta_{\mathrm{H}} 2.31\right)$ to C-2 $\left(\delta_{\mathrm{C}} 58.0\right), \mathrm{C}-4\left(\delta_{\mathrm{C}} 15.8\right)$, and C-5 $\left(\delta_{\mathrm{C}} 18.9\right)$; from $\mathrm{H}-4\left(\delta_{\mathrm{H}} 0.93\right)$ to $\mathrm{C}-2, \mathrm{C}-3\left(\delta_{\mathrm{C}} 31.7\right)$, and C-5; as well as from $\mathrm{H}-5\left(\delta_{\mathrm{H}} 0.90\right)$ to C-2, C-3, and C-4 showed the presence of isopropyl-substitute in 3 instead of 2-butylsubstitute in $\mathbf{1}$. Thus, the diketopiperazine fragment of $\mathbf{3}$ includes valine residue (Val) instead of Ile in $\mathbf{1}$.
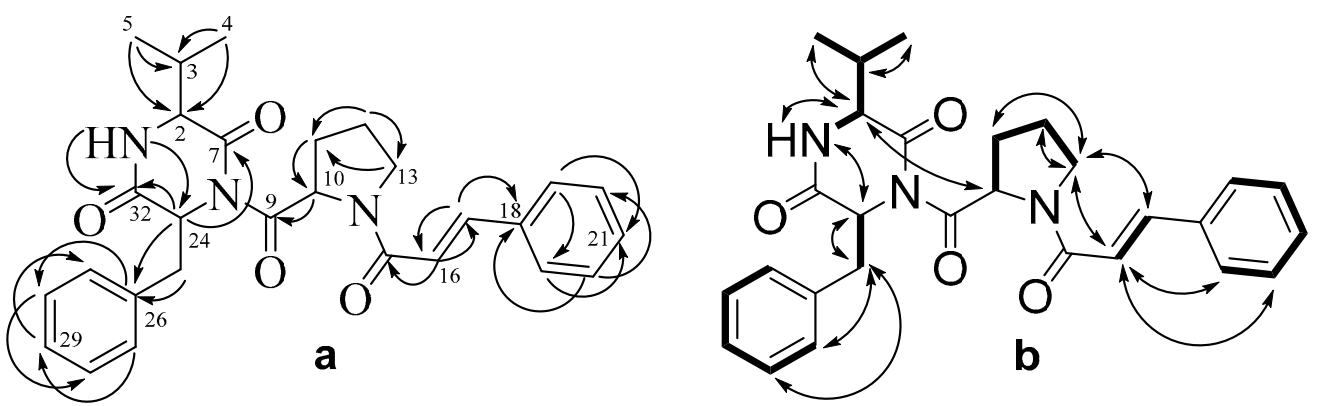

Figure 4. The key HMBC (a) and ${ }^{1} \mathrm{H}^{-1} \mathrm{H}$ COSY and ROESY (b) correlations of 3.

The absolute configurations of all stereocenters in $\mathbf{3}$ were established in the same way as in compounds $\mathbf{1}$ and 2, by Marfey's method. An analysis of L-FDAA derivatives of amino acid residues obtained by acid hydrolysis of compound 3 showed them to be derivatives of $L$-Val, $L$-Pro, and D-Phe standard samples (Figures S33-S36, Supplementary Material). Thereby, the configurations of chiral centers at C-2, C-10, and C-24 were determined to be $2 S, 10 S$, and $24 R$, respectively. Compound 3 was named asterripeptide $C$.

It should be noted that cinnamic acid and its derivatives are widespread among plant metabolites [22,23]. However, these compounds were never reported as fragments of any fungal metabolites. Thus, this is the very first report of cinnamic acid containing compounds from marine microfilamentous fungus. We suggest that cinnamic acid was produced in the fungus from phenylalanine via phenylalanine-ammonia-lyase enzyme action, similar to its biosynthesis in plants [24]. A similar enzyme was earlier reported for Aspergillus orizae [25]. 
Table 3. ${ }^{1} \mathrm{H}$ and ${ }^{13} \mathrm{C}$ NMR spectroscopic data ( $\delta$ in ppm, $\mathrm{CDCl}_{3}$ ) for 3.

\begin{tabular}{|c|c|c|c|c|c|c|}
\hline & Pos. & $\delta_{C}$, Mult & $\delta_{\mathrm{H}}(J$ in $\mathrm{Hz})$ & НМВС & COSY & ROESY \\
\hline \multirow{6}{*}{ Val } & 1 & $(\mathrm{NH})$ & 5.67, brs & $2,8,23,31$ & 2 & 2,24 \\
\hline & 2 & $58.0, \mathrm{CH}$ & $2.60, \mathrm{~d}(2.7)$ & $3,4,5,7$ & 3 & 5 \\
\hline & 3 & $31.7, \mathrm{CH}$ & $2.31, \mathrm{~m}$ & $2,3,4,5,7,31$ & $2,4,5$ & 1,4 \\
\hline & 4 & $15.8, \mathrm{CH}_{3}$ & $0.93, \mathrm{~d}(6.8)$ & $2,3,5$ & 3 & 1,3 \\
\hline & 5 & $18.9, \mathrm{CH}_{3}$ & $0.90, \mathrm{~d}(7.1)$ & $2,3,4$ & & 2 \\
\hline & 7 & $170.2, \mathrm{C}$ & & & & \\
\hline \multirow{9}{*}{ Pro } & 9 & $174.6, \mathrm{C}$ & & & & \\
\hline & 10 & $61.6, \mathrm{CH}$ & $5.11, \mathrm{dd}(8.6,3.7)$ & $9,11,12$ & 11 & 2,11 \\
\hline & & & $2.14, \mathrm{~m}$ & $9,10,12$ & 10,12 & 13 \\
\hline & 11 & 29.7, $\mathrm{CH}_{2}$ & $2.48, \mathrm{~m}$ & 9,12 & 10,12 & 13 \\
\hline & 12 & $24.4 \mathrm{CH}_{2}$ & $2.18, \mathrm{~m}$ & 10,13 & & $12 b$ \\
\hline & 12 & $24.4, \mathrm{CH}_{2}$ & $2.08, \mathrm{~m}$ & 10,13 & & $12 a, 12 b$ \\
\hline & & & $3.79, \mathrm{~m}$ & 11,12 & $\begin{array}{l}10,11 b \\
12 a, 12 b\end{array}$ & $15,11 b$ \\
\hline & 13 & $47.6, \mathrm{CH}_{2}$ & $3.94, \mathrm{~m}$ & 11,12 & $10,11 \mathrm{~b}$ & $15,11 \mathrm{a}$ \\
\hline & 15 & $164.6, \mathrm{C}$ & & & $12 \mathrm{a}, 12 \mathrm{~b}$ & \\
\hline \multirow{8}{*}{ CA } & 16 & $117.8, \mathrm{CH}$ & $6.72, \mathrm{~d}(15.5)$ & $15,17,18,19 / 23$ & 17 & $\begin{array}{c}13 a, 13 b \\
19 / 23 \\
20 / 22\end{array}$ \\
\hline & 17 & $142.9, \mathrm{CH}$ & $7.66, d(15.6)$ & $15,16,18,19 / 23$ & 16 & $13 a, 13 b$ \\
\hline & 18 & $135.1, \mathrm{C}$ & & & & \\
\hline & 19 & $127.9, \mathrm{CH}$ & $7.50, \mathrm{~d}(6.9)$ & 21,23 & 20 & 16 \\
\hline & 20 & $128.8, \mathrm{CH}$ & 7.35, brd (1.4) & 17,21 & 19,21 & 16 \\
\hline & 21 & 129.7, CH & $7.34, \mathrm{~m}$ & 19,23 & 20,22 & \\
\hline & 22 & $128.8, \mathrm{CH}$ & 7.35, brd (1.4) & 18,20 & 21,23 & 16 \\
\hline & 23 & $127.9, \mathrm{CH}$ & $7.51, \mathrm{~d}(7.8)$ & $17,19,21$ & & 16 \\
\hline \multirow{10}{*}{ Phe } & 24 & $59.8, \mathrm{CH}$ & $5.22, \mathrm{t}(4.5)$ & $7,9,25,26,32$ & & \\
\hline & & & $3.28, \mathrm{dd}(14.0,5.0)$ & $25,27 / 31,32$ & 29 & $27 / 31,28$ \\
\hline & 25 & $38.6, \mathrm{CH}_{2}$ & $3.34, \mathrm{dd}(14.0,4.0)$ & $25,27 / 31,32$ & 29 & $27 / 31,28$ \\
\hline & 26 & $134.9, \mathrm{C}$ & & & & \\
\hline & 27 & $130.6, \mathrm{CH}$ & 7.10, d (1.7) & $25,27,29$ & & 10,24 \\
\hline & 28 & $128.7, \mathrm{CH}$ & $7.29, \mathrm{~m}$ & $26,29,31$ & & \\
\hline & 29 & $127.9, \mathrm{CH}$ & $7.29, \mathrm{~m}$ & 27,31 & & \\
\hline & 30 & $128.7, \mathrm{CH}$ & $7.29, \mathrm{~m}$ & $26,27,29$ & & \\
\hline & 31 & $130.6, \mathrm{CH}$ & $7.10, \mathrm{~d}(1.7)$ & $25,27,29$ & & 10,24 \\
\hline & 32 & $168.2, \mathrm{C}$ & & & & \\
\hline
\end{tabular}

Bioassays

The cytotoxic activities of isolated compounds 1-3 are presented in Table 4. Each one showed a weak cytotoxic activity toward non-malignant cardiomyocyte H9c2 cells as well as human colorectal DLD-1 and breast cancer MCF-7 cells. The cytotoxic effect of compounds 1-3 against human prostate cancer PC -3 cells was not great either, but it was observed at lesser concentrations.

Table 4. Cytotoxic activity of asterripeptides A-C (1-3).

\begin{tabular}{ccccc}
\hline \multirow{2}{*}{ Compound } & \multicolumn{5}{c}{ IC $_{\mathbf{5 0}}, \boldsymbol{\mu M}$} \\
\cline { 2 - 5 } & MCF-7 & DLD-1 & PC-3 & H9c2 \\
\hline $\mathbf{1}$ & $96.8 \pm 7.0$ & $87.7 \pm 5.3$ & $64.6 \pm 2.4$ & $76.7 \pm 5.2$ \\
$\mathbf{2}$ & $>100$ & $>100$ & $75.5 \pm 1.9$ & $104.1 \pm 3.3$ \\
$\mathbf{3}$ & $96.6 \pm 1.5$ & $84.9 \pm 7.4$ & $58.3 \pm 3.2$ & $87.6 \pm 4.5$
\end{tabular}

All experiments were carried out in independent three experiments. Data are presented as a mean \pm standard mean error. 
Asterripeptide A (1) half-maximal decreased the viability of MCF-7 and DLD-1 cells at 96.8 and $87.7 \mu \mathrm{M}$, respectively, whereas it decreased the viability of PC-3 cells at the concentration of $64.6 \mu \mathrm{M}$. Asterripeptide B (2) half-maximally decreased the viability of MCF-7 and DLD-1 cells at a concentration larger than $100 \mu \mathrm{M}$, whereas it decreased the viability of PC-3 cells at the concentration of $75.5 \mu \mathrm{M}$. Finally, asterripeptide $\mathrm{C}(3)$ decreased the viability of MCF-7 and DLD-1 cells by $50 \%$ at 96.6 and $84.9 \mu \mathrm{M}$, respectively, whereas it decreased the viability of PC-3 cells at the concentration of $58.3 \mu \mathrm{M}$. Thus, cytotoxicity of asterripeptides A-C (1-3) was not great, but some selectivity of these compounds for prostate cancer cells may be of particular interest.

To determine antibacterial properties, the possibility of isolated compounds inhibiting enzymatic activity of the sortase A was investigated. The membrane-associated sortase A enzyme (EC 3.4.22.70) is one of the key enzymes for Staphylococcus aureus virulence, and its inhibitors are considered as potential anti-bacterial agents [26]. Thus, asterripeptides B (2) and C (3) inhibited sortase A activity by more than $20 \%$ at the concentration of $80 \mu \mathrm{M}$ and asterripeptide A (1) was inactive in this assay (Figure 5).

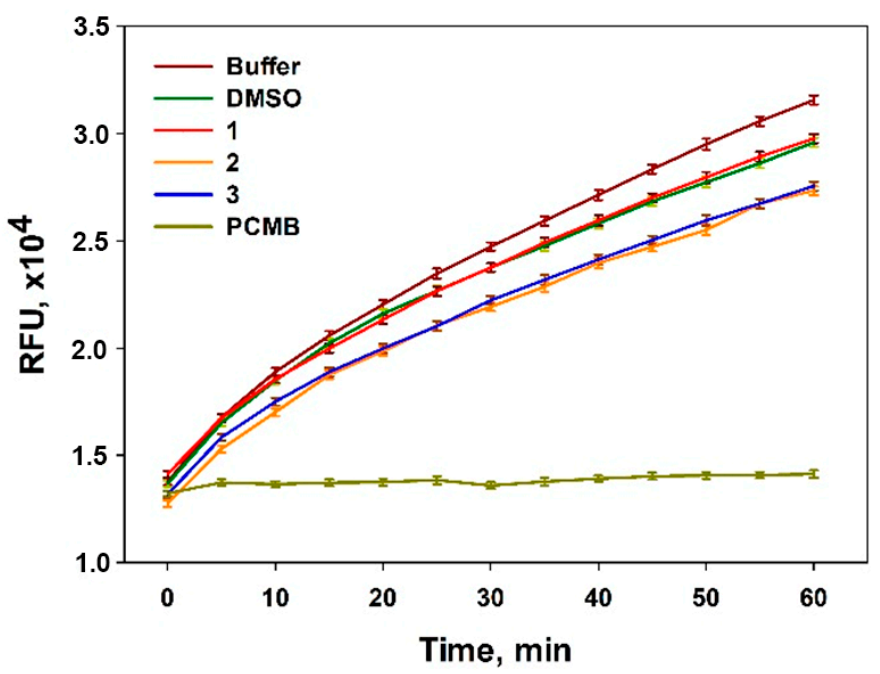

Figure 5. Effects of asterripeptides A-C (1-3) on the enzymatic activity of sortase A. Reaction kinetics of sortase $\mathrm{A}$ in the presence of isolated compounds $(80 \mu \mathrm{M})$ and selective inhibitor 4 (hydroxymercuri)benzoic acid (PCMB) are at the same level of substrate concentration. DMSO $(0.8 \%)$ was used as a vehicle.

Earlier bicyclic peptides with Leu-Pro-Pro motive were identified as potent and selective inhibitors of sortase A via binding to the enzyme's active site, owing to structural mimicking of the Leu-Pro-Xaa-Thr-Gly region of natural substrate of sortase A [27]. Presumably, the presence of the terminal ethyl group in isoLeu is the main reason for the inactivity of asterripeptide A, and the Leu-Pro fragment in the structure of asterripeptide B (2) as well as the Val-Pro region in the structure of asterripeptide C (3) play a role in their sortase A inhibitory effect. Thus, asterripeptides B and C are worthy of note as promising anti-Staphylococcal agents, and their antibacterial activity will be investigated in detail in the future.

\section{Materials and Methods}

\subsection{General Experimental Procedures}

NMR spectra were recorded in $\mathrm{CDCl}_{3}$ on a Bruker DPX-500 (Bruker BioSpin $\mathrm{GmbH}$, Rheinstetten, Germany) and a Bruker DRX-700 (Bruker BioSpin GmbH, Rheinstetten, Germany) spectrometer, using TMS as an internal standard. HRESIMS spectra were measured on a Maxis Impact mass spectrometer (Bruker Daltonics $\mathrm{GmbH}$, Rheinstetten, Germany).

Low-pressure liquid column chromatography was performed using silica gel $(50 / 100 \mu \mathrm{m}$, Imid Ltd., Krasnodar, Russia). Plates $(4.5 \mathrm{~cm} \times 6.0 \mathrm{~cm})$ precoated with silica gel $(5-17 \mu \mathrm{m}$, 
Imid Ltd.) were used for thin-layer chromatography. Preparative HPLC was carried out on a Shimadzu LC-20 chromatograph (Shimadzu USA Manufacturing, Canby, OR, USA) using a YMC ODS-AM (YMC Co., Ishikawa, Japan) $(5 \mu \mathrm{m}, 10 \mathrm{~mm} \times 250 \mathrm{~mm})$ and YMC SIL (YMC Co., Ishikawa, Japan) $(5 \mu \mathrm{m}, 10 \mathrm{~mm} \times 250 \mathrm{~mm})$ columns with a Shimadzu RID-20A refractometer (Shimadzu Corporation, Kyoto, Japan). Analysis of amino acids' stereo configurations was performed on an Agilent 1100 chromatograph using YMC C-18 Pro column (YMC Co., Ishikawa, Japan) $(5 \mu \mathrm{m}, 4.6 \mathrm{~mm} \times 250 \mathrm{~mm})$.

\subsection{Fungal Strain}

The strain was isolated from mangrove tree leaves Kandelia candel (coast of Khanh Hoa province, Vietnam, South China Sea) on malt extract agar, and identified based on morphological and molecular features. For DNA extraction, the culture was grown on malt extract agar under $28^{\circ} \mathrm{C}$ for 7 days. DNA extraction was performed with the HiPurA ${ }^{\mathrm{TM}}$ Plant DNA Isolation kit (CTAB Method) (HiMedia Laboratories Pvt. Ltd., Mumbai, India) according to the manufacturer's instructions. Fragments containing the ITS regions were amplified using ITS1 and ITS4 primers. The newly obtained sequences were checked visually and compared to available sequences in the GenBank database (https:/ / www.ncbi. nlm.nih.gov/genbank, accessed on 16 December 2021). According to BLAST analysis of the ITS1-5.8S-ITS2 sequence, the strain LM.1.5 had 98.06\% similarity with Aspergillus terreus DTO 403-C9 (sequence number in GenBank database-MT316343.1). The sequences were deposited in the GenBank nucleotide sequence database under MN788658.1.

\subsection{Cultivation of Fungus}

The fungus was cultured at $28^{\circ} \mathrm{C}$ for three weeks in $40 \times 500 \mathrm{~mL}$ Erlenmeyer flasks, each containing rice $(20.0 \mathrm{~g})$, yeast extract $(20.0 \mathrm{mg}), \mathrm{KH}_{2} \mathrm{PO}_{4}(10 \mathrm{mg})$, and natural sea water $(40 \mathrm{~mL})$.

\subsection{Extraction and Isolation}

The fungal mycelia with the medium were extracted for $24 \mathrm{~h}$ with $12 \mathrm{~L}$ of EtOAc. Evaporation of the solvent under reduced pressure gave a dark red-brown oil (6.50 g), to which $250 \mathrm{~mL} \mathrm{H}_{2} \mathrm{O}-\mathrm{EtOH}$ (4:1) was added, and the mixture was thoroughly stirred to yield a suspension. It was extracted successively with hexane $(100 \mathrm{~mL} \times 3)$, EtOAc $(150 \mathrm{~mL} \times 3)$, and $n-\mathrm{BuOH}(150 \mathrm{~mL} \times 2)$. After evaporation of the EtOAc layer, the residual material $(4.00 \mathrm{~g})$ was passed through a silica gel column $(11 \mathrm{~cm} \times 4 \mathrm{~cm}, 75 \mathrm{~g})$, which was eluted first with n-hexane $(1.0 \mathrm{~L})$, followed by a step gradient from $5 \%$ to $100 \%$ EtOAc in $n$-hexane (total volume $25 \mathrm{~L}$ ). Fractions of $250 \mathrm{~mL}$ each were collected and combined based on the TLC results (silica gel and toluene-2-propanol, 6:1 and 3:1, v/v).

The AT-1-40 (470.08 mg) fraction eluted by the $n$-hexan-EtOAc system (85:15) was separated by an LH-20 column $(80 \mathrm{~cm} \times 2 \mathrm{~cm}, 50 \mathrm{~g})$ with $\mathrm{CHCI}_{3}$ to yield subfraction AT-27-1 (50.62 mg). Subfraction AT-27-1 was purified by HPLC on a YMC-SIL column, eluting with $n$-hexan-EtOAc (50:50) to yield compounds 1 (7.94 mg) and 2 (4.63 mg). The AT-101-69 (154 mg) fraction eluted by $n$-hexan-EtOAc system (75:25) was separated by LH-20 column $(80 \mathrm{~cm} \times 2 \mathrm{~cm}, 50 \mathrm{~g})$ with $\mathrm{CHCI}_{3}$ to yield subfraction AT-103-13 (33.64 mg). The subfraction AT-103-13 was purified by HPLC on a YMC ODS-AM with $\mathrm{MeCN}-\mathrm{H}_{2} \mathrm{O}$ (75:25) to yield 3 (3.41 $\mathrm{mg})$.

Asterripeptide A (1): colorless oil; ${ }^{1} \mathrm{H}$ and ${ }^{13} \mathrm{C}$ NMR data, see Table 1, Figures S1-S7; HRESIMS $[\mathrm{M}-\mathrm{H}]^{-} 486.2473$ (calc. for $\mathrm{C}_{29} \mathrm{H}_{32} \mathrm{~N}_{3} \mathrm{O}_{4}, 486.2471$ ).

Asterripeptide B (2): colorless oil; ${ }^{1} \mathrm{H}$ and ${ }^{13} \mathrm{C}$ NMR data, see Table 2, Figures S9-S15; HRESIMS [M + Na] $]^{+}$439. 2367 (calc. for $\mathrm{C}_{29} \mathrm{H}_{33} \mathrm{~N}_{2} \mathrm{O}_{5} \mathrm{Na}, 510.2369$ ).

Asterripeptide C (3): colorless oil; ${ }^{1} \mathrm{H}$ and ${ }^{13} \mathrm{C}$ NMR data, see Table 3, Figures S17-S23; HRESIMS [M + Na] $]^{+} 496.2203$ (calc. for $\mathrm{C}_{28} \mathrm{H}_{31} \mathrm{~N}_{3} \mathrm{O}_{4} \mathrm{Na}$, 496.2207). 


\subsection{Stereo Configuration Analysis of Amino Acids in Compounds 1-3}

The compounds $(0.2 \mathrm{mg}$ each) were placed in glass ampoules and dissolved in $6 \mathrm{~N} \mathrm{HCl}$ $(0.4 \mathrm{~mL})$. Solutions in ampoules were frozen in liquid nitrogen, then vacuumed, sealed, and heated at $105^{\circ} \mathrm{C}$ for $24 \mathrm{~h}$. Then, the cooled reaction mixture was diluted by distilled water and concentrated in vacuo [21]. The obtained hydrolysates of compounds 1-3 and standard amino acids of the $L$ - and $D$-configurations ( $0.2 \mathrm{mg}$ each) were dissolved in $0.1 \mathrm{~mL}$ of distilled water, then $0.4 \mathrm{~mL}$ of $1 \mathrm{M} \mathrm{NaHCO}_{3}$ and $0.2 \mathrm{~mL}$ of a $1 \%$ solution of Marfey's reagent in acetone were added. The reaction mixtures were kept at $37^{\circ} \mathrm{C}$ for $75 \mathrm{~min}$ and $0.05 \mathrm{~mL}$ of $1 \mathrm{M} \mathrm{HCl}$ was added. Then, obtained $L$-FDDA derivatives were analyzed by HPLC-UV in gradient of $\mathrm{MeCN}_{-} \mathrm{H}_{2} \mathrm{O}$ from 25:75 to $65: 35$ over 40 min at $20{ }^{\circ} \mathrm{C}$ using YMC C-18 Pro column.

\subsection{The Effect of Compounds 1-3 on Sortase A Enzymatic Activity}

The enzymatic activity of sortase A from Staphylococcus aureus was determined using SensoLyte 520 Sortase A Activity Assay Kit * Fluorimetric * (AnaSpec AS-72229, AnaSpec, San Jose, CA, USA) in accordance with the manufacturer's instructions. DMSO at a concentration of $0.8 \%$ was used as a control. Fluorescence was measured with the plate reader PHERAStar FS (BMG Labtech, Offenburg, Germany) for 60 min with a time interval of $5 \mathrm{~min}$. The data were processed by MARS Data Analysis v. 3.01R2 (BMG Labtech, Offen-burg, Germany). The results were presented as relative fluorescent units (RFUs) and percentage of the control data [28].

\subsection{Cell Lines and Culture Conditions}

The human prostate cancer PC-3, human breast cancer MCF-7, and human colorectal cancer DLD-1 cells were purchased from ATCC. The rat cardiomyocytes H9c2 line cells were kindly provided by Prof. Dr. Gunhild von Amsberg from Martini-Klinik Prostate Cancer Center, University Hospital Hamburg-Eppendorf, Hamburg, Germany. The cells were cultured in DMEM medium (Biolot, St. Petersburg, Russia) containing $10 \%$ fetal bovine serum (Biolot, St. Petersburg, Russia) and 1\% penicillin/streptomycin (Invitrogen, Carlsbad, CA, USA) at $37^{\circ} \mathrm{C}$ in a humidified atmosphere with $5 \%(v / v) \mathrm{CO}_{2}$. Initially, cells were incubated in cultural flasks until sub-confluent $(\sim 80 \%)$. For testing, the cells were seeded at concentrations of $5 \times 10^{3}$ cells/well (MCF-7, DLD-1, and PC-3 cells) or $1 \times 10^{3}$ cells/well (H9c2 cells), and experiments were started after $24 \mathrm{~h}$ (MCF-7, DLD-1, and PC-3 cells) or $48 \mathrm{~h}$ (H9c2 cells).

\subsection{In Vitro MTT-Based Cytotoxicity Assay}

The in vitro cytotoxicity of individual substances was determined by the MTT (3(4,5-dimethylthiazol-2-yl)-2,5-diphenyltetrazolium bromide) method, according to the manufacturer's instructions (Sigma-Aldrich, St. Louis, MO, USA).

Investigated compounds were dissolved in DMSO at a concentration of $10 \mathrm{mM}$. This solution was used to obtain the required concentration of compounds in the cell suspension, so that the concentration of DMSO in the cell suspension would not exceed $1 \%$.

The cells were treated with the investigated compounds for $24 \mathrm{~h}$, and MTT reagent was added to each well of the plate. The vehicle with DMSO at the concentration of $1 \%$ was used as a control. The absorbance of formed formazan was measured at $\lambda=570 \mathrm{~nm}$, using a Multiskan FC microplate photometer (Thermo Scientific, Waltham, MA, USA) and expressed in optical units (o.u.). The results were calculated as \% of viable cells to vehicle data.

\subsection{Statistical Data Evaluation}

All results were given as a mean \pm standard error of the mean (SEM). General statistical analysis was performed using Student's $t$-test, employed with the aid of SigmaPlot 14.0 (Systat Software Inc., San Jose, CA, USA). Differences were considered statistically significant at $p<0.05$. 
Supplementary Materials: The following supporting information can be downloaded at: https: / / www.mdpi.com/article/10.3390/md20010077/s1, Figures S1-S7, S9-S15 and S17-S23: NMR spectra of compounds 1-3; Figures S8, S16 and S24: MS data for compounds 1-3; Figures S25-S36: HPLC profiles of FDAA derivatives for compounds 1-3.

Author Contributions: Formal analysis, E.V.G. and E.A.Y.; Funding acquisition, O.I.Z.; Investigation, E.V.G., A.B.R., R.S.P., E.A.Y., E.A.C., P.T.H.T., N.T.D.N. and M.V.P.; Methodology, E.V.G., E.A.Y. and A.N.Y.; Project administration, P.T.H.T. and A.N.Y.; Resources, A.N.Y.; Supervision, A.N.Y.; Validation, E.A.Y. and A.N.Y.; Visualization, E.V.G. and E.A.Y.; Writing-original draft, E.V.G.; Writing-review \& editing, E.A.Y. and A.N.Y. All authors have read and agreed to the published version of the manuscript.

Funding: This research was funded by Russian Science Foundation, grant number 19-74-10014 (chemical study), and Vietnam Academy of Science and Technology, grant QTRU01.03/21-22 (microbiological study).

Institutional Review Board Statement: Not applicable.

Informed Consent Statement: Not applicable.

Data Availability Statement: Not applicable.

Acknowledgments: The authors are grateful to Tatyana N. Makarieva and Alla G. Guzii (PIBOC FEB RAS, Vladivostok, Russia) for help with Murfey's method; to Irina N. Gladkikh, Oksana V. Sintsova, and Rimma S. Kalina PIBOC FEB RAS, Vladivostok, Russia) for equipment provided for Murfey's analysis; as well as to Lyudmila Y. Tischenko (PIBOC FEB RAS, Vladivostok, Russia) for technical assistance in peptide hydrolysis. The study was carried out on the equipment of the Collective Facilities Center "The Far Eastern Center for Structural Molecular Research (NMR/MS) PIBOC FEB RAS".

Conflicts of Interest: The authors declare no conflict of interest. The funders had no role in the design of the study; in the collection, analyses, or interpretation of data; in the writing of the manuscript; or in the decision to publish the results.

\section{References}

1. Varga, J.; Samson, R.A. Aspergillus in the Genomic Era; Wageningen Academic Publishers: Wageningen, The Netherlands, 2008; pp. $1-334$.

2. Uras, I.S.; Ebada, S.S.; Korinek, M.; Albohy, A.; Abdulrazik, B.S.; Wang, Y.-H.; Chen, B.-H.; Horng, J.-T.; Lin, W.; Hwang, T.-L.; et al. Anti-inflammatory, antiallergic, and COVID-19 main protease (Mpro) inhibitory activities of butenolides from a marine-derived fungus Aspergillus terreus. Molecules 2021, 26, 3354. [CrossRef] [PubMed]

3. Inamori, Y.; Kato, Y.; Kubo, M.; Kamiki, T.; Takemoto, T.; Nomoto, K. Studies on metabolites produced by Aspergillus terreus var. aureus. I. Chemical structures and antimicrobial activities of metabolites isolated from culture broth. Chem. Pharm. Bull. 1983, 31, 4543-4548. [CrossRef] [PubMed]

4. Li, H.L.; Li, X.M.; Yang, S.Q.; Meng, L.H.; Li, X.; Wang, B.G. Prenylated phenol and benzofuran derivatives from Aspergillus terreus EN-539, an endophytic fungus derived from marine red alga Laurencia okamurai. Mar. Drugs 2019, 17, 605. [CrossRef]

5. Liu, W.; Xu, W.; Zeng, X.; Cheng, Z.; Li, Q.; Li, Y. Aspterrics A and B, new sesquiterpenes from deep sea-derived fungus Aspergillus terreus YPGA10. Rec. Nat. Prod. 2020, 14, 18-22. [CrossRef]

6. Tsuda, Y.; Kaneda, M.; Tada, A.; Nitta, K.; Yamamoto, Y.; Iitaka, Y. Aspterric acid, a new sesquiterpenoid of the carotane group, a metabolite from Aspergillus terreus IFO-6123. X-ray crystal and molecular structure of its p-bromobenzoate. J. Chem. Soc. Chem. Commun. 1978, 4, 160-161. [CrossRef]

7. Cane, D.E.; Whittle, Y.G.; Liang, T.C. Sesquiterpene biosynthesis: The biosynthesis of quadrone and terrecyclic acid. Bioorg. Chem. 1986, 14, 417-428. [CrossRef]

8. Ling, K.H.; Yang, C.K.; Peng, F.T. Territrems, tremorgenic mycotoxins of Aspergillus terreus. Appl. Environ. Microbiol. 1979, 37, 355-357. [CrossRef] [PubMed]

9. Arai, K.; Yamamoto, Y. Metabolic products of Aspergillus terreus X: Biosynthesis of asterriquinones. Chem. Pharm. Bull. 1990, 38, 2929-2932. [CrossRef]

10. Huang, X.; Men, P.; Tang, S.; Lu, X. Aspergillus terreus as an industrial filamentous fungus for pharmaceutical biotechnology. Curr. Opin. Biotechnol. 2021, 69, 273-280. [CrossRef] [PubMed]

11. Khaldi, N.; Seifuddin, F.T.; Turner, G.; Haft, D.; Nierman, W.C.; Wolfe, K.H.; Fedorova, N.D. SMURF: Genomic mapping of fungal secondary metabolite clusters. Fungal Genet. Biol. 2010, 47, 736-741. [CrossRef] 
12. Gao, H.; Guo, W.; Wang, Q.; Zhang, L.; Zhu, M.; Zhu, T.; Gu, Q.; Wang, W.; Li, D. Aspulvinones from a mangrove rhizosphere soil-derived fungus Aspergillus terreus Gwq-48 with anti-influenza A viral (H1N1) activity. Bioorg. Med. Chem. Lett. 2013, 23, 1776-1778. [CrossRef] [PubMed]

13. Liu, M.; He, Y.; Shen, L.; Anbari, W.H.A.; Li, H.; Wang, J.; Qi, C.; Hu, Z.; Zhang, Y. Asperteramide A, An unusual N-Phenylcarbamic acid methyl ester trimer isolated from the coral-derived fungus Aspergillus terreus. Eur. J. Org. Chem. 2019, 2019, 2928-2932. [CrossRef]

14. He, F.; Bao, J.; Zhang, X.-Y.; Tu, Z.-C.; Shi, Y.-M.; Qi, S.-H. Asperterrestide A, A cytotoxic cyclic tetrapeptide from the marinederived fungus Aspergillus terreus SCSGAF0162. J. Nat. Prod. 2013, 76, 1182-1186. [CrossRef]

15. Chaiyosang, B.; Kanokmedhakul, K.; Boonmak, J.; Youngme, S.; Kukongviriyapan, V.; Soytong, K.; Kanokmedhakul, S. A new lumazine peptide penilumamide e from the fungus Aspergillus terreus. Nat. Prod. Res. 2016, 30, 1017-1024. [CrossRef]

16. Agrawal, S.; Acharya, D.; Adholeya, A.; Barrow, C.J.; Deshmukh, S.K. Nonribosomal peptides from marine microbes and their antimicrobial and anticancer potential. Front. Pharmacol. 2017, 8, 828. [CrossRef]

17. Sieber, S.A.; Marahiel, M.A. Learning from Nature's drug factories: Nonribosomal synthesis of macrocyclic peptides. J. Bacteriol. 2003, 185, 7036-7043. [CrossRef]

18. Daniel, J.F.D.S.; Rodrigues Filho, E. Peptaibols of trichoderma. Nat. Prod. Rep. 2007, 24, 1128-1141. [CrossRef]

19. Youssef, F.S.; Ashour, M.L.; Singab, A.N.B.; Wink, M. A comprehensive review of bioactive peptides from marine fungi and their biological significance. Mar. Drugs 2019, 17, 559. [CrossRef]

20. Girich, E.V.; Yurchenko, A.N.; Smetanina, O.F.; Trinh, P.T.; Ngoc, N.T.; Pivkin, M.V.; Popov, R.S.; Pislyagin, E.A.; Menchinskaya, E.S.; Chingizova, E.A.; et al. Neuroprotective metabolites from vietnamese marine derived fungi of Aspergillus and Penicillium genera. Mar. Drugs 2020, 18, 608. [CrossRef]

21. Fujii, K.; Shimoya, T.; Ikai, Y.; Oka, H.; Harada, K.-I. Further application of advanced Marfey's method for determination of absolute configuration of primary amino compound. Tetrahedron Lett. 1998, 39, 2579-2582. [CrossRef]

22. De, P.; Baltas, M.; Bedos-Belval, F. Cinnamic acid derivatives as anticancer agents-A review. Curr. Med. Chem. 2011, 18, 1672-1703. [CrossRef] [PubMed]

23. Lafay, S.; Gil-Izquierdo, A. Bioavailability of phenolic acids. Phytochem. Rev. 2008, 7, 301-311. [CrossRef]

24. Hahlbrock, K.; Scheel, D. Physiology and molecular-biology of phenylpropanoid metabolism. Annu. Rev. Plant Physiol. Plant Molec. Biol. 1989, 40, 347-369. [CrossRef]

25. Seshime, Y.; Praveen, R.J.; Fujii, I.; Kitamoto, K. Genomic evidences for the existence of a phenylpropanoid metabolic pathway in Aspergillus oryzae. Biochem. Biophys. Res. Commun. 2005, 337, 747-751. [CrossRef] [PubMed]

26. Guo, Y.; Cai, S.; Gu, G.; Guo, Z.; Long, Z. Recent progress in the development of sortase A inhibitors as novel anti-bacterial virulence agents. RSC Adv. 2015, 5, 49880-49889. [CrossRef]

27. Rentero Rebollo, I.; McCallin, S.; Bertoldo, D.; Entenza, J.M.; Moreillon, P.; Heinis, C. Development of potent and selective $S$. aureus sortase A inhibitors based on peptide macrocycles. ACS Med. Chem. Lett. 2016, 7, 606-611. [CrossRef]

28. Chingizova, E.A.; Menchinskaya, E.S.; Chingizov, A.R.; Pislyagin, E.A.; Girich, E.V.; Yurchenko, A.N.; Guzhova, I.V.; Mikhailov, V.V.; Aminin, D.L.; Yurchenko, E.A. Marine fungal cerebroside flavuside B protects HaCaT keratinocytes against Staphylococcus aureus induced damage. Mar. Drugs 2021, 19, 553. [CrossRef] [PubMed] 